Constructions of social justice, marginalization, and belonging

\title{
$\mathrm{Li}$, Yongjian
}

Oxford University Press

2019-04

Li , Y \& Dervin , F 2019 , Constructions of social justice, marginalization, and belonging . in G W Noblit (ed.), Oxford Research Encyclopedias : Education . Oxford University Press , Oxford . https://doi.org/10.1093/acrefore/9780190264093.013.132

http://hdl.handle.net/10138/309626

https://doi.org/10.1093/acrefore/9780190264093.013.132

acceptedVersion

Downloaded from Helda, University of Helsinki institutional repository.

This is an electronic reprint of the original article.

This reprint may differ from the original in pagination and typographic detail.

Please cite the original version. 


\section{Constructions of Social justice, Marginalisation and Belonging}

Yongjian Li \& Fred Dervin

Summary: The theme of social justice appears to be central in education research today. A polysemic and sometimes empty notion, social justice can be defined, constructed and used in different ways, which makes it a problematic notion to work with intra- and inter-culturally. Global education research has often relied on constructions of the notion as they have been 'done' in the West, leaving very little space to constructions from peripheries. This problematic and somewhat biased approach often leads to research that ignores local contexts and local ways of 'discoursing' about social justice. Although some countries are said to be better at social justice in education (e.g. top performers in the OECD PISA studies), there is a need to examine critically and reflexively how it is 'done' in different contexts ('winners' and 'losers' of international rankings) on macro- and micro-levels. Two different educational utopias, China and Finland, are used to illustrate the different constructions of social justice, and more specifically marginalisation and belonging in relation to migrant students - an omnipresent figure in today's world education - in the two countries. A call for learning with each other about social justice, and questioning too easily accepted definitions and/or formulas, is made.

Keywords: social justice, migrant education, marginalization, comparative education, China, Finland 


\section{Introduction}

For Bialystok (2014), the notion of social justice is the "apple pie of contemporary education work" but also, somewhat, "a feel-good phrase". In education around the world today, there appear to be contradictions between current practices of neoliberalism (marketisation, economisation, the 'ranking' culture) and omnipresent calls for social justice. Rikowski (2000), amongst others, even goes as far as arguing that social justice cannot exist in times like ours.

Although we agree with these critiques, in writing this article, we believe that "education and society are intrinsically inter-related and that the fundamental purpose of education is the improvement of social justice for all" (McArthur, 2010: 493). As such, the topic of social injustice is a critical problem everywhere and no country can claim not to face some of its many and varied woes in education. Some might appear to fare better than others, depending on how they are evaluated for doing so (see e.g. PISA 2015 results on performance and equity).

Rather than offering a static definition of the concept, which would be necessarily biased, limited/limiting and very much related to our own ideologies, this chapter problematizes constructions of social justice in education, linking the concept to the central issues of marginalization and belonging. We wish to make our readers aware of the fact that, conceptually, politically, philosophically or in relation to practices, defining social justice is a challenging task, that deserves our critical and reflexive attention.

First, social justice is present as a concept in many different academic disciplines such as political philosophy, geography, history, social work, and psychology (e.g. Shriberg, Song, 
Miranda \& Radliff, 2013). This makes it a highly interdisciplinary concept, with an already long history.

Second, according to Sen (2002), different contexts as well as groups might have a different understanding of social justice. As such, social justice is both an intercultural but an intracultural issue. Even within a given context or group (e.g., parents vs. teachers; minority vs. majority students, etc.), its meanings and the ways it is experienced may be disparate, inconsistent, tacit and even underexplored. For Bogotch (2013: 57), "Each of the 190 plus nations is challenged to re-center how it defines educational quality to meet the needs of its nation's citizens, not just constitutionally. As a result, social justice itself is made relevant contextually across geographic locations around the world”. Politics, socioeconomics, amongst others, also have a big influence on the instability of the concept. In order to make it a valuable addition to research on education, there needs to be explicit discussions of what it means or ought to mean. There is also a need to document better how it is practiced in schools.

Third, besides social justice being polysemic (Rizvi, 1998: 47) it might go hand in hand with different other (polysemic) concepts such as inclusion/exclusion, equality/equity, etc. In education research around the world, although one might have the illusion that the concept is 'universal' in terms of what it refers to and in relation to practices, the use of locally connoted words to refer to it in/directly and explicitly/implicitly might make social justice even more difficult to construct and negotiate across borders.

The foci of this article are the followings. 
In the first part of the article, inspired by the work of Rodriguez Medina (2014) on the circulation of knowledge within globalization, we discuss the importance of critically evaluating knowledge production about social justice in education, especially between the 'centre' (the hegemonic 'West') and 'peripheries' (Africa, Asia, and South America) (Batur, 2014). This serves as a caveat about working with the polysemic idea of social justice in relation to marginalization and belonging.

There is then a need to map the complex territory of social justice in education. We ask how it has been problematized and defined. Considering the hegemony of research from North American and some European countries in relation to issues of social justice, we also turn to the periphery, in this case, China, to explore the ways the concept is discussed in Chinese education.

One aspect of social justice that seems to have been debated in many and varied contexts is that of fighting against marginalization, and creating a sense of belonging amongst those who experience it. The concept of sense of belonging is defined here as "one aspect of students' important emotional connectedness with their school, school belonging represents students' perceptions of the social context of schooling and their place in it, including their feelings of being respected and safe in their particular school" (Liu et al., 2015: 1271). In this sense, social justice occurs when education can boost students' sense of belonging, within education and beyond. Our second interest is thus in reviewing research on these issues from different contexts. 'Migrant students', a central polymorphic figure of today's global education, is used as a way of exploring these issues. Using the case of China and Finland (our contexts of practice and research), where the issue of migrant students is central to research on social justice in education, we examine the problems of social injustice faced by these students and, if possible, 
solutions that the two countries have found to deal with their multifaceted marginalization. We start from the idea that neither of these two countries knows how to deal perfectly with social justice in education. We would like to suggest that both countries can actually learn with each other about this issue. Looking at the case of China is, again, a way of refocusing our attention to the periphery in education.

All in all, this article examines how social justice is understood, 'done' and the possibilities education can offer. We also introduce critical lenses to highlight the hidden ideologies in discussions of social justice, marginalization and belonging.

\section{Critically evaluating knowledge production about social justice in education}

It has become a truism to admit that the concept of social justice is a very complex one. As we shall see, it is enmeshed in both local and global discourses, often tainted by historical, economic, political, social and epistemic discussions emerging especially from the centre but also the periphery in which they take place. This means that discourses of social justice can cross different "sites of conflicting and divergent political endeavours" (Rizvi, 1998: 47).

The main questions that should be borne in mind as a consequence is: Whose conception(s) of social justice is/are to be applied in education? Whose voice(s)? And why should they be rather than others'?

When acquainting oneself with the international literature on social justice in education, we can see with Rodriguez Medina (2014) that a 'coloniality of knowledge' is actively taking place: 'Western' scholarship seems to determine how to talk (words to use, even ready-made 
assertions), analyse (methods) and interpret (conclusions, recommendations) social justice in education. Although a lot of knowledge might be produced locally on social justice issues in education, often only production in English is valued and somewhat regarded as 'scientific' (Harper, 2011). Besides very few titles in other languages than English get translated into English. Scholars from the periphery thus have to publish in certain top-ranking international journals, speaking the same language as others and referring to key studies and scholars who have also published in English, to guarantee publication. In many peripheral contexts researchers are often trained abroad and bring back with them certain ways of seeing and analysing the social world. Although they might alter the acquired knowledge for the local context, often, they will try to apply what they have learnt abroad to their work, without always questioning the meanings e.g. concepts and methods are given locally. Finally, many scholars from the centre do research on the periphery and decide, somehow, what is to be said about it, how it is to be said and what conclusions can be drawn from these.

Let us take the case of China to illustrate.

In Can China Think? Anne Cheng (2008) explains that China started opening to the world in the 1980s and that the Middle Kingdom has built up ever since a strong academic "bridge" or "highway" over the Pacific Ocean with the American academic world. Thousands of students go to study in American universities and either work in the USA or return to China for work after graduation. Many Chinese academics have been trained in the USA and have acquired and internalized - a specific social justice language, quoting classics such as Rawls, Dworkin, Young and using words such as oppression and marginalization, to talk about the situation of rural migrants in China, for example (Luo, Zhong \& Tsang, 2015). For Cheng (2008), these can easily lead to the process of self-orientalization, culturalism (culture as an excuse, see 
Dervin, 2016), decontextualization of knowledge but also mistranslation. Let us take the idea of tolerance, which is often said to be an expected outcome of multicultural/intercultural education and social justice. In Chinese, the word has at least two different meanings (Cambridge Dictionary):

1. willingness to accept behaviour and beliefs that are different from your own, although you might not agree with or approve of them (宽容 ; 忍受 ; 容忍).

2. the ability to deal with something unpleasant or annoying, or to continue existing despite bad or difficult conditions (忍耐力 ; 忍受力).

Using the word in English, without problematizing its meanings in Chinese could easily lead to misunderstandings if compared to the meaning(s) given to the word in English as a global academic language (Holmes et al., 2016). It might also put wrong words in participants' mouths.

Although Cheng (2008) notes that the revival of tradition and "national learning" (guoxue; 国 学) has also emerged in Chinese intellectual circles, with a reclaim of the past, to our knowledge, no scholar has attempted to problematize social justice in Chinese education through 'local' knowledge (being in English or Chinese). Jinghe Han (2017) gives an interesting example of how this could be done in language education by exploring the relationship between Chinese Hanzi（汉字） and knowledge generation. She argues (ibid.: 7) that "Hanzi orthography has the properties of early Chinese people's understanding of the relationship between epistemology and ontology." She continues: (as a new pedagogical framework, Hanzi method) "includes: real-world connection through daring imagination, universal logical thinking, empathetic/moral understanding of human experiences and critical 
conceptualisation of the complexity of the world". Although this is a necessary step to 'glocalizing' (embedding the local and the global in a more meaningful way) we agree with Cheng (2008: n.p.) that "We must therefore remain wary about the conditions and purposes of this reclaiming process, which is taking place in a very explosive ideological context".

As asserted earlier, there is also a risk in the centre examining the periphery from its own perspectives and ideologies. The volume The China Questions: Critical Insights into a Rising Power (2018) co-edited by Rudolph and Szonyi tends to fall into this trap. Covering a range of topics about China (politics, economy, society, environment, etc.), the book promises to cut through "the cacophony of information, misinformation, and nonsense on China that circulates in our modern world to give us reliable answers to crucial questions about one of the world's most important nations". However, looking at the list of (mostly Western) authors and the list of chapters (controversial issues discussed in the West), one gets the impression of China being treated like "a museum piece, an "Other" with which to be compared, to make it respond to totally irrelevant questionings" (Cheng, 2008: n. p.).

In an article entitled Comparing and contrasting how social justice is 'done' in education? Critical reflections on China and Finland (Li \& Dervin, 2017), we reflected on the issue of Othering in comparative education after visiting rural schools in China and Finland. Our first reaction was to try to identify 'good' practices of social justice in the Finnish context (which is said to be one of the 'best' education systems in the world, especially in terms of equality/equity), as inspiration for China. At first sight, obviously, when comparing the schools and contexts, rural schools in Finland appear to be more modern, better equipped, and the teachers more motivated than the Chinese ones. However, do these really tell us the whole story about how social justice is 'done' in the two contexts, especially beyond international 
rankings? We felt a need to dig deeper into concrete practices of social justice in the two contexts to see beyond appearances. We also felt that an approach that concentrates mostly on differences between these contexts led to biases and moralistic judgments (Holliday, 2013) and that there was thus a need to work within a continuum of differences and similarities. What we noticed was that at a micro-level (teachers' practices), similar strategies were used in the two contexts and that, in a sense, the Chinese teachers took the issue of social justice more at heart than their Finnish counterparts (Li \& Dervin, ibid.).

At a macro-level, one also notices that both China and Finland seem to emphasise justice, equality-equity. For instance, many words included in China's Core Socialist Values, which are divided into three categories (national, social and individual) the values of democracy (national), equality and justice (social) and dedication and friendship (individual) are included (Zhao, 2014). These values represent Chinese socialism as promoted at the $18^{\text {th }}$ National Congress of the Communist Party of China in 2012. What these values mean in their English translation or in reality is difficult to decipher. Scholars like Yang (2016) have noted that Chinese education faces different kinds of social injustice, that would contradict these values, especially at the structural level (see below about migrant students). In Finland, the idea of equality is included in the Constitution (731/1999), where equality of the sexes is said to be "promoted in societal activity and working life, especially in the determination of pay and the other terms of employment, as provided in more detail by an Act". However, although Finland, like other Nordic countries, is regarded as one of the most gender-equal countries in the world there are still very strong gender equality problems in the Nordic country, especially in relation to the gender pay gap (Saari, 2011). In their 2016 article entitled Subtle discourses on equality in the Finnish curricula of upper secondary education: reflections of the imagined society, Lappalainen and Lahelma note that the idea of equality has been present in Finnish educational 
politics and policies for the past 40 years. They explain that the meaning and conceptualization of the concept have changed with the political orientations of different periods of time. They also show that a clear neo-liberal educational restructuring into Finland is noticeable in their diachronic study of the presence of the word equality in policy documents.

It is easy to see through the above discussions that social justice is a multi-layered ideal construct that can easily refer to a contested and contentious concept (Troyna \& Vincent, 1995).

\section{Social justice in education: A short (Western) historical overview}

“The more I tried to give it [social justice] a definite meaning, the more it fell apart (...)" (Hayek, 1976: xi)

In this section, we examine the multiple ways in which social justice in education has been problematized and defined from interdisciplinary perspectives in the sizable literature produced about it.

Historically, according to Novak (2000), the phrase social justice seems to have been first used in the $19^{\text {th }}$ Century by the Italian Catholic priest and philosopher Antonio Rosmini (17971855). In his book The Constitution Under Social Justice (2007), he tried to integrate theology, philosophy and economics of a social order that aspired to be both free and just. Although the word social justice might have been uttered for the first time then, it is clear that the idea of justice itself had been discussed in many other parts of the world many centuries before. The anthropologist Jack Goody (2006: 2) calls this phenomenon the theft by the West of the achievements of others in the invention of certain ideas such as democracy, individualism and 
even justice. This argument is important when one tries to define social justice in education and thus urges us to look beyond Western scholarship to explore other ways of problematizing and implementing social justice in education. As a reminder, when we started writing this article, we soon discovered that academic periphery, in our case China, spoke about social justice in education in very similar ways as e.g. American scholarship. The fact that most quoted publications on the topic are in English have an influence on who quotes what and for what purposes.

Obviously, this is very problematic. As such there tends to be easily accepted definitions that emerged from e.g. the USA during the Civil Rights Movements. These are specific to this historical context and, the ideas or words associated with social justice, may not be relevant to other contexts. For instance, the famous American scholar, specialised in multicultural education, Ch. Sleeter, argued in 2014 that "Most people agree on its broad principles |[social justice], such as these: "1) Equity, the principle of fairness. . . 2) Activism, the principle of agency. . . [and] 3) Social literacy, the principle of relevance." When Sleeter talks about most people, who does she refer to? People in Europe, North America and/or Asia? Although we might argue that justice is something meaningful to most people, is it really correct to say that social justice has 'broad principles' that are agreed upon by everyone? Other scholars have demonstrated that education researchers analyse education policy through different lenses, thus reflecting different conceptions of social justice.

In his article on education leadership and social justice, Bogotch (2013) suggests that one can adopt at least two attitudes to defining social justice in education. 1. One starts with a definition and verifies if collected data correspond to the aspects of the definition: "the researcher concludes that social justice was found (rarely not) through this particular empirical study" 
(ibid.: 56). 2. One starts from a broader approach, arguing that words are polysemic and that the context and those involved in it will (re)negotiate them during the research process. He suggests asking the following questions: “(...) are individuals, groups, or even nations capable of creating socially just conditions for others? How do the meanings of social justice vary across cultures?" (ibid.). He concludes by arguing, rightly we believe, that "We should be sceptical, therefore, when we read or hear a single definition of social justice in a strict semantic sense" (ibid.).

Canonical voices are often heard in international scholarship on social justice in education. Some of these (mostly Western) voices are presented in what follows. Scholars (e.g. Luo, Zhong \& Tsang, 2015) often start with Plato, the philosopher in Classical Greece, who has deconstructed and reconstructed the different meanings of justice and injustice in his most influential work The Republic. For the philosopher, justice is a virtue establishing rational order. In the dialogue, Socrates wonders if the just or the unjust person benefits more. He also suggests what the proper role of citizens in a just society should be, thus making the idea of justice universal.

Throughout European history, many thinkers have dealt with the idea of justice but they are rarely mentioned in scholarship on social justice in education (e.g. (Medieval Christianity) Augustine, Aquinas; (Early Modernity) Hobbes, Hulme; (Recent Modernity) Kant, Mill).

Rawls' (1971) A Theory of Justice appears to be a must in the field of education. A work of political philosophy and ethics, the book tries to deal with the issue of distributive justice (the socially just allocation of goods in a society) by means of a theory Rawls called Justice as Fairness. The theory is twofold: 1 . there is a need to structure societies that give the best access 
to liberty, as long as it does not impede onto others' liberty; 2. Beneficial inequality should be 'done' if the worst off are better off than under an equal distribution: social and economic inequalities are to be arranged so that they are both (a) reasonably expected to be to everyone's advantage, and (b) attached to positions and offices open to all (1971). For Rawls (ibid.), justice refers to the distribution of rights, duties and the social and economic goods accruing from social cooperation.

Another influential voice in discussions of social justice in education is that of the AustrianBritish economist and philosopher Frederick Hayek (1899-1992), the 'father' of so-called neoliberalism. In his work on social and political philosophy, Volume III called the Mirage of Social Justice (1976), Hayek argued that "social justice is an empty phrase with no determinable content" (ibid.: 68), "will-o-the-wisp" (ibid.: 99), "a quasi-religious belief with no content whatsoever" (ibid.: xi-xii). The economist believed in individual freedom and disapproved of distributive justice from the State, calling it a threat to liberty and freedom. Iris Young (1949-2006), who was a political theorist and feminist at the University of Chicago, argued that social justice should be more than the distribution of resources and that decisions about social justice should take into account differences between people and contexts (1990). She explained, and that is important for us in this chapter, that issues related to social justice such as marginalization, exploitation and powerlessness (amongst others) must be "rethought" (1990: 258). For the scholar, "justice includes opportunity, self-respect, autonomy, decisionmaking, cultural capital, and rights”. Yet, Nancy Fraser (1997: 2-3), another 'big name' in discussions of social justice, worries about the fact that such ideological approaches to social justice represent a problematic shift from discussions of justice as redistribution to justice as recognition. Fraser (ibid.) argues that redistributive justice still matters today and that a 
recognition approach to social justice solely seems to lay too much emphasis on 'culture', 'race' and 'ethnicity' but somewhat ignores the power of finance.

This short historical review of how Western influential ideas concerning social justice is being talked about in education could confirm that the 'West' is seen as the source for knowledge about social justice (Singh, 2011). There is a need for alternative voices to be heard so that alternative but also somewhat complementary voices can be heard.

\section{Multiple definitions of social justice in education - insights from the 'Centre'}

In what follows we try to review multiple definitions of social justice in education. As indicated in the title of this article, we talk about 'constructions' of social justice. How is the term constructed today in education, in specific contexts? Can the multiple definitions of the word be used in other contexts, i.e. be reconstructed for other contexts? We argue from the start that there cannot be a universal agreement on what social justice in education means, refers to and how it can be dealt with. However, in many contexts, there seems to be an agreement that social justice is both a goal and a process (see Bell, 1997).

It is important to note first with Yates and MacLeod (2000: 59) (inspired by David Hamilton) that "'social justice' is a considerably more problematic concept at this present point in history than social injustice". Second considering the amount of publications on social justice emerging from North America, one can easily say that it is a centre of knowledge production on social justice in education, which has had a lot of influence on the rest of the world. In the USA, social justice in education encompasses a set of active principles and practices for implementing and even teaching about social justice. Paying attention to and making educators 
and students aware of hidden curricula for instance is a way to fight against larger societal dynamics of power and inequality (institution, society). It is obvious in the following necessarily selective review of models of social justice in education that societal, political and philosophical discourses on diversity and difference from the North American context have had a big impact on the models.

Let us start with education policy. In her 1998 publication, Gewirtz sketches out a framework for conceptualizing social justice in the context of education policy research, using Young's work (see previous section). Through her work, she asks how, to what extent and why education policies support, interrupt and subvert the following elements. Gewirtz (1998: 482) names them the five different 'faces of oppression':

“1. Exploitative relationships (capitalist, patriarchal, racist, heterosexist, disablist, etc.) within and beyond educational institutions?

2. Processes of marginalization and inclusion within and beyond the education system? 3. The promotion of relationships based on recognition, respect, care and mutuality or produce powerlessness (for education workers and students)?

4. Practices of cultural imperialism? And which cultural differences should be affirmed, which should be universalized and which rejected?

5. Violent practices within and beyond the education system?"

Based on Bell's (1997) work, Hackman (2006) follows a very similar path when she lists the following characteristics of what she calls social justice education:

- students' encouragement in taking an active role on their education; 
- support of teachers in creating empowering, democratic and critical educational environments;

- equitable distribution of resources and social responsibility;

- careful attention paid to the systems of power and privilege that give rise to social inequality.

In her article, Hackman proposes to demonstrate how educators can utilize a social justice pedagogical lens to treat their content in ways that meet their commitment to empowering education (five components: Content mastery, tools for critical analysis, tools for social change, tools for personal reflection, an awareness of multicultural group dynamics). However, Wang (2013) warns against letting teachers make all the (pedagogical) decisions about empowering students. Teachers' perceptions and perspectives cannot but be ideologically biased. She suggests (ibid.) that both teachers and students negotiate together the ways they want social justice to be set as a goal in class (and beyond) and how it should be integrated and discussed in class activities.

The fields of multicultural and intercultural education have also had a strong impact on the definition of different models of social justice specifically for the classroom. American scholar and educational reformer Christine Sleeter (2015) summarized different frameworks for social justice education for teachers through the following four dimensions:

1. Reject interpreting problems of students mainly as personal failures but by looking at the effects of unfair policies and systems (e.g. limited access to health care) and their influence within and outside the school and classroom.

2. Develop reciprocal relationships with students and families (encouraging, building trust, listening to parents, etc.). 
3. Have high academic expectations by using the students' intellectual resources.

4. Create and teach a curriculum integrating marginalised perspectives and discussions of social justice.

The next point relates to a social justice issue which has been labelled as either culturally responsive or culturally relevant teaching (e.g. Gay, 2010). These 'multicultural'/'diverse' approaches suggest that students' cultural backgrounds be taken into account in classrooms in order to "expose the unequal and unjust social and pedagogical reality of marginalization, to advocate redistribution of power and wealth, and to promote social activism for a better world" (Wang, 2013: 487). This approach to social justice tends to be marked by American multicultural politics (Abdallah-Pretceille, 1999). Interculturalists have warned about the potential dangers of such ideologies since they too easily seem to oppose minority vs majority. Furthermore, they tend to give too much power to the concept of culture, which can often become an excuse, an alibi, or a way of marginalizing and segregating more (Dervin, 2016; Holliday, 2013). Dervin (2016) has proposed an approach to social justice based on the idea of interculturality without culture ('critical interculturality'), which takes into account discussions of similarity and difference, critical intersectionality, power relations and discursive constructions of 'us' and 'them'.

Finally, it is important to note that an increasing number of studies on social justice in education call for strong political engagement. For Nieto (2000: 183) social justice means "analysing school policies and practices... that devalue the identities of some students while overvaluing others". Bialystok (2014: 418) takes a broader perspective in what follows: "[social justice education] takes up to various degrees the goals of anti-oppression politics, anti-colonialism, environmentalism, and a critique of corporate globalization, with more or less overt sympathy 
for the social welfare state and resistance to educational policies characteristic of neoliberalism. It tends to depend on or endorse a robust notion of democracy and sees education as an indispensable site of social and political participation."

As a counterpoint to the aspects presented until now, we wish to discuss how ideas related to social justice, marginalization and belonging are being constructed and negotiated in China. While reviewing the literature in English and Chinese about social justice in Chinese education, one notices that there appears to be a lack of critical engagement with the concept and its companions such as equity, equality, etc. As we shall see in the next section, there is a wide range of studies on Chinese populations that experience social injustice in education such as rural students, migrant students or children 'left behind' by parents who have moved to cities to find a job. These studies note the problems these individuals encounter but very few attempts to contribute to their alleviations (through e.g. action research). The few studies that were identified to try to problematize social justice in relation to e.g. rural students tend to use the knowledge presented above, from the American context (see e.g. Luo, Zhong \& Tsang, 2015).

In Chinese scholarship, especially in the field of education, Communist party politics have an influence on what one researches, how one researches it and under which terms. Education is state-run in China and the government funds a nine-year compulsory education (Compulsory Education Law of 1986). In what follows we summarize Xue and Liu's review of Xi Jinping's Educational Thoughts: The Banner and Direction of China's Educational Reform (2017). The General Secretary of the Party and President of the People's Republic of China, Xi Jinping, has been very influential in making many significant education policies since the beginning of his office. These have been influential in education research too. Based on the idea of the 'Chinese Dream', Xi aims to help poor families to provide adequate, see high-quality, schooling for their 
children. The concept of Educational fairness (教育公平), which is at the centre of these policies, is somewhat close to the idea of social justice. The main focus is poverty-stricken places (mostly rural) and areas populated by some of China's 55 ethnic groups. Xi has also insisted on the importance of ensuring education equality to enhance social equality. He writes: "Measures should be taken to ensure that all girls have access to school and safe schooling, developing women's vocational education and lifelong education to help them adapt to social and job market changes." $\mathrm{Xi}$ has promised to promote vocational education to support manufacturing and alleviate poverty in certain regions. $\mathrm{Xi}$ has also insisted on making the teaching profession one of the most valuable professions in today's China and that teachers needed to have 'sound ethics' (in relation to socialist core values), first-class teaching abilities and high levels of happiness and accomplishment. Teachers should also "use love to cultivate love" and "nourish the students' hearts". In his writings, Xi explains that "teachers are important; teachers' work shapes the soul, life and work of the people."

As we can see from Xue and Liu's (2017) review, social justice in education in China corresponds very much to a distributive approach to justice. It also covers some aspects of recognition but from a less political perspective than what was proposed in the American context. Finally, the emphasis is very much on teachers' pedagogical skills and motivations, although nothing is said about how they can themselves support concretely 'educational fairness' beyond the classroom.

Before we move on to the next and final section of this article, which will present examples of studies on social justice in relation to the marginalization of migrant students in China and Finland, we would like to summarize what has been said until now. The idea of social justice in education is a multifaceted one, which deals with both educational goals and processes. 
Although there seems to be implicit agreement on its meaning in international research, especially from a global Americano-centric perspective, very much influenced by discourses from the USA, there are different models of social justice within a given sphere and in other ones. As the idea of social justice appears to be 'floating', it can clearly be used to impose certain interpretations as the right one. It also means that there cannot always be a common strategy to 'do' it, from within or across countries. There is a need for researchers around the world to communicate and to learn with each other about how to improve social justice in education.

\section{4. 'Doing' social justice in education: Comparison of migrant students in China and} Finland

In this final subsection, we wish to compare how the issue of social justice in relation to marginalization and belonging is dealt with in two very different contexts, which are our own professional contexts. Our goal here is not to say that one context is better or worse than the other but to examine critically the differences and similarities in how they deal with issues of marginalization in/through education. At first sight, China and Finland have very little in common. While the People's Republic of China has a population of 1.4 billion people, Finland's population is 5.4 million. The Nordic country covers an area of $338,424 \mathrm{~km}^{2}$ and China 9.6 million. China is a unitary one-party socialist republic while Finland a unitary parliamentary republic. China has 56 nationalities (55 minorities) and Finland has one official minority (Swedish-speakers, 5.29\% of the population) and a recognized regional language (Sami with $0.04 \%$ of the population). The two countries' Gross Domestic Products are: $\$ 23.2$ trillion (\$16,676 per capita; China) and \$239.662 billion (\$43,545; Finland) (ESA.UN.org). 
Finally, China has the largest education system in the world with 474,000 schools, 10 million teachers and 200 million students (China Education and Research Network, 2011).

Although they are very different, these two countries both represent 'educational utopias' today. The word utopia was coined by English statesman, lawyer, philosopher and Renaissance humanist Sir Thomas Moore. The etymology of the word is from the Greek ou-topos meaning 'no place' or 'nowhere' (Giroux, 2003). In 1516, Moore published Utopia about an imaginary ideal nation with highly coveted and/or nearly perfect qualities. China and Finland represent different types of utopias, especially in relation to their excellent positions in international rankings in education. Many countries wish to copy Finland for e.g. her fun-learning approaches, student-centeredness and autonomous learning-teaching. China is inspiring for e.g. mathematics education to the rest of the world. As asserted in the introduction, on the one hand, Finland is said to lay a strong emphasis on equality and social justice, on the other hand, China is often said to be hierarchical, competitive and a victim of varied inequalities (Zhao, 2014).

Yet what these two countries have in common is migrant populations in schools. In Finland, migrant children comprise different populations: newly arrived children from another country, refugees but also, sometimes, certain children, born in Finland, but whose parents migrated to Finland (so-called 'second-generation') (Dervin et al., 2013). In China, (internal) migrant students are usually from rural areas and have moved to urban areas with their parents to get better job opportunities. Like migrant students in Finland, they might speak a different language/dialect, have a different religion and different cultural habits. Both countries face, on different scales, problems of social injustice and especially marginalisation. In what follows we present some of these issues for both countries. The end of the section takes a look at initiatives that have been reported in research to deal with the problems migrant students face. 


\subsection{Migrant students in Finland: Social justice as a façade?}

The Nordic country of Finland, member of the European Union since 1995, currently has a population of 300,000 immigrants $(5.4 \%$ of the entire population) who speak over 150 languages (Statistics Finland, 2016; the biggest foreign-language speaking groups: Russian speakers $(72,436)$, Estonian speakers $(48,087)$ and Somali speakers $(17,871)$.

Finnish students' success in international comparisons of student assessments (such as the OECD's PISA) in the last decade has been celebrated at the national level and remained a topic of interest internationally. Finnish students' performance has been among the best in all the domains in each PISA cycle, albeit on the decline in the latest one (e.g. Sahlberg, 2015). According to the Finnish National Board of Education (FNBE), education is seen as a key to competitiveness and well-being of the society.

Education has long had a reputation as a basic right of all citizens and, until today, is provided free of charge. Quality, efficiency, equity and internationalization stand out as key terms in Finnish education policies. The values of Finnish education comprise quality and equality/equity regardless of nationality, race or socio-economic backgrounds. This is reflected in the fact that Finland guarantees immigrants the same educational opportunities as the majority. The Act on the Promotion of Immigrant Integration, which came into force in 2011, aims at promoting integration into Finnish society and advocates support for participation and integration. Different measures and strategies for social justice and against marginalization are defined for the parents of immigrant families: "Key services for families with children are the services provided at child welfare clinics, early childhood education, basic education and pupil welfare services". Two institutions deal with education and training for immigrants at all levels 
of education: The Ministry of Education and Culture and the National Board of Education. Municipalities are relatively free to implement education and thus to integrate immigrants in education in whatever ways. Aid is granted to them to provide instruction in Finnish or Swedish as a second language and pupils' own native languages. Finally, many government-funded NGOs contribute to working towards educational integration.

In spite of all the fame that Finnish education has recently received, it does not mean that there is no room or need for development. According to recent studies by Finnish researchers Bernelius (2013), Riitaoja (2013) and Kalalahti \& Varjo (2012), among others, educational equality in Finland has weakened due to increasingly neo-liberal policies and the repeated economic crises since 2008. Studies also show that Finland has been facing threats of youth marginalization (FNBE, 2014), lower performance of boys, Swedish-speakers, and immigrants (Kilpi-Jakonen 2011), and reduced well-being at comprehensive schools (Harinen \& Halme, 2012). According to the OECD (2015) school dropout among people with an immigrant background is higher than in other EU countries.

For example Elina Kilpi-Jakonen (2012) showed that, regardless of current policies and measures, children of specific immigrant groups tended to have lower levels of school achievement at the end of comprehensive school than the majority and that their lower parental resources (parental education, parental labour force participation, parental income, parental socioeconomic status, and household composition; Unemployed amongst immigrants: $26.9 \%$ for $1^{\text {st }}$ generation and $29.9 \%$ for second generation versus $8,8 \%$ for the majority) were partly the reason. The measure of school achievement in Kilpi-Jakonen's work is the average grade in the comprehensive-school finishing certificate (ibid.: 170). While 96.5 of the majority leave school with a certificate, only $30.4 \%$ of first generations and 69.6 second generations from West Asia and North Africa (Iraq, Turkey and Iran) graduate from comprehensive school 
(ibid.).

Recent discussions concerning the 2012 Finnish results for the triennial Programme for International Student Assessment (PISA) also reveal that 15-year-old immigrants are at least 2 years behind other students in mathematics, science, reading literacy, and problem-solving performances and that many do not reach the minimum level required (Harju-Luukkainen et al., 2014). This is not specific to Finland as many other countries in Europe face the same issue. Yet, according to the Finnish report, first generation immigrants lag two school years behind and second-generation immigrants slightly less behind the majority.

One central issue in the integration of immigrants in mainstream education is represented by the transition and continuation of immigrants to upper secondary education in Finland and then to higher education. Elina Kilpi-Jakonen (2011) notes that first generations immigrants are less likely to continue in general schools than the majority and the second generation. She also explains that there are differences between groups of immigrants, for instance, Sub-Saharan first generation students are most likely to drop out, non-Europeans more than Europeans. Poor skills in the Finnish language but also the inability of Finnish as a Second Language teachers to prepare them properly are given as explanations. Prior school achievement and family resources also seem to play a role.

The importance of location is also increasingly deemed important in the treatment of immigrants and refugees in the Finnish context. Large cities such as Helsinki, Espoo and Turku have recently experienced changing patterns of spatial socioeconomic and ethnic differentiation (e.g. Seppänen, Kalalahti, Rinne \& Simola, 2015). These patterns directly impact housing and school choices and the ways schools operate (Bernelius, 2013). The 
phenomenon of school shopping is detected in the larger urban areas (Seppänen et al., 2015;), while disadvantaged neighbourhoods are rejected by many parents (Kosunen, 2014; Seppänen, et al., 2015). Linnansaari-Rajalin et al. (2015) show a link between the socioeconomic status of a school neighbourhood and teachers' work commitment, especially in terms of organisational commitment. This indicates a potential increase of inequalities in children's learning opportunities. In reaction to this, the city of Helsinki, amongst others, has built rental flats in the same areas as owner-occupied flats in order to create an economically and socially and ethnically diverse population.

Many recent studies have also examined more in depth the development of language education policies in Finland - language being a central aspect of integration into education. The results are not always positive. For instance, Suni and Latomaa (2012) note that there tends to be a gap between the policies and their actual implementation. The two researchers write: "Finland might seem like an educational paradise, a place where all students are ensured equal opportunities (...) However, the actual grassroots reality of immigrant students may be quite different, and one may well ask whatever they really do enjoy a satisfactory level of equality" (Suni \& Latomaa, 2012: 68). They thus draw the conclusion that practices are still largely monolingually oriented in Finnish education and that L1s have a weak status (ibid.). They explain this by reminding that current legislation does not force the providers of education to take the specific needs of immigrant students into account (ibid.). In a similar vein VoipioHuovinen and Martin (2014) claim that many class supervisors in basic education in the Helsinki Greater Area show a lack of interest in immigrant students. This is explained by the fact that these teachers are often overworked and lack the skills to deal with immigrants. This is why more professional development is needed regarding this matter. 
In their 2016 report entitled Finnish as a second language syllabus learning outcomes in the 9th grade of basic education in 2015, the Finnish Education Evaluation Centre (FINEEC) shows that amongst the 1,530 pupils who participated in the study (which included $66 \%$ of pupils who had been granted intensified or special support) the language proficiency was fairly good (Kuukka \& Metsämuuronen, 2016). 87\% had reached a threshold level (B1.1/B1.2), with their comprehension skills being stronger than their production ones. The pupils who performed best were Estonian, Russian, Chinese and English-speaking, regardless of how many years they had attended school in Finland. The pupils' socioeconomic background was also one of the factors explaining their learning outcomes, again, regardless of the amount of years spent in Finland.

Finally, Finnish teacher education is increasingly contributing to problematize social justice in relation to the education of immigrants. Teacher education plays a key role in shaping the future of education. According to Menter (2016: 3), teacher education influences the "practice of teachers in schools and colleges and thereby [it has] a strong effect on the quality of educational experiences for learners". Many programs based on multicultural, intercultural, social justice and/or global teacher education aim at preparing teachers for working with and for immigrant students (Dervin \& Hahl, 2015; Jokikokko, 2010). It is important to note that approaches to social justice often rely on American perspectives and that no 'Finnish' approach has been developed although there have been attempts at problematizing a 'Nordic' approach to promote justice in education (e.g. the Nordic Centre of Excellence Justed http://www.justed.org). Although words such as inclusion and equality/equity are omnipresent in discussing education, these words are nearly absent from e.g. the recent review article entitled The last 40 years in Finnish teacher education (Tirri, 2014). Teacher education is multiform in the country. Depending on the department and university, emphases might differ. Some student teachers 
might get specific courses on social justice in education, while others may not. Social justice might also be limited to e.g. knowledge on different cultures, worldviews and religions and the development of an ethno-relative position amongst student teachers (e.g. Kuusisto et al., 2016) or it might be substituted by multicultural/intercultural education especially in relation to migrant students (Layne \& Dervin, 2016). Some courses might concentrate on gender diversity (Brunila \& Kallioniemi, 2017). The research interests and ideologies of professors and lecturing staff have a direct influence on what, how and why student teachers study specific aspects of social justice. We also note with Brunila and Kallioniemi (2017: 4-5) that many initiatives related to social justice in Finnish teacher education "has become caught up in project-based activities. The rise of project-based work or projectisation (...) is a part of a larger societal shift towards market economics that has started to challenge the Nordic welfare states.". This means that social justice education in Finnish teacher education is often shortterm and somewhat short-sighted.

\subsection{China: From structural injustice to micro-level realities}

It is not easy to identify the number of (internal) migrant children living in Chinese cities. In the early 2010 s the number of migrant population was approx. 221 million, or $16.5 \%$ of the total Chinese population (National Bureau of Statistics of China, 2011). According to All China Women's Federation approx. 35 million migrant children were based in urban settings in 2013. Since the 1990s the issue of the education of migrant children is a much-discussed topic in Chinese education research. Thousands of articles have been published on this specific population to discuss the discriminatory role of the residence permit system $(\mathrm{Hukou})$ on migrants' rights to enter urban schools (e.g. Wong, Li \& Song, 2007), as well as their total numbers and the issues they face (Han, 2004). The Hukou system determines access to local social welfare services, such as housing, health care, and education for their children. School 
access has also been an important research interest. In 2001 the 'two primary responsibilities' (两项基本责任) policy was passed in China, which facilitated the access of urban schools to migrants. Like in the Finnish context, the policy proposes "equal treatment of the local students and the migrant students" (Article 4) in terms of school participation, awards, extracurricular activities as well as tuition and fees (General Office of State Council (2003). However migrant students still have lower education opportunities than other children, as there are no financial incentives to support local schools to accommodate them. Local governments get financed based on students officially registered in the region. Since migrant students are not registered, schools are hesitant to welcome them. However, it is important to note that some school districts administrators have encourages teachers to work in inclusive classrooms and to provide them with professional development programmes to work with migrant students.

After the 2003 policy most researchers seem to have shifted their attention to more empirical studies looking at schooling processes and outcomes, psychological health and adaptation of the children (e.g. Zhang \& Luo, 2017; Wang \& Gao, 2013). According to Zhang \& Luo (ibid.), "their findings reported that migrant children as a whole experienced loneliness, anxiety and sense of inferiority in public schools and had difficulties in school performance compared with the local peers". These results are similar to the Finnish context where migrant students are reported as not meeting the minimum skill level (see Harju-Luukkainen et al., 2014).

In what follows we explore several such studies related to marginalization.

In a study on two primary schools in Shanghai, Wang and Holland (2012) note that migrant students encounter more and stricter admission procedures and requirements and more onerous financial burdens. They also explain that no special aid is provided to help them adapt to the 
new environment. In general, the physical conditions of these public schools and the quality of the teaching personnel left to be desired.

In a 2016 paper, Zhang and Luo (2016) provide us with an interesting study on how certain Beijing schools deal with migrant students. Using a micro-ethnographic perspective, they reveal the hidden mechanisms of social exclusion of the children in urban school practices. Three elements contributing to marginalization were identified: access to school through finding ways of convincing the school of the children's worth (the school often feels it is doing them a 'service'), in-class participations (migrant children might have inadequate skills to deal with e.g. urban oriented contents) and peer interactions (extra-curricular activities are too expensive for the children to participate and socialize with the locals). These represent what the authors call the 'hidden curriculum' which works against migrant children and lead to their marginalization and exclusion. They add:

Although discourses of inclusion and equity permeate government policy documents, our ethnographic fieldwork on the everyday life of migrant children in a Beijing public school suggests that the emphasis on 'equal treatment' is only superficial and fails to take into account of the migrant children's disadvantaged status and special educational needs. Under the disguise of 'equal treatment', migrant children are subject to learning in a swim-or-sink way and tend to be excluded in many aspects of urban school life. (ibid.: 230)

In their study, Lu and Zhou (2012) ask researchers to pay attention to contexts when researching migrant students. They measured the assimilation and well-being of migrant students in Beijing's public schools and informal migrant schools. The latter are usually set up 
by migrant communities to cater for children, who cannot study at public schools. There are many reasons why migrant students will not be allowed to register at a local school: They are often the targets of prejudice, they might have to pass an exam before enrolling while urban children are not required to, etc. (ibid.). In their comparison, the scholars found that the migrant children in public schools achieved better than in the migrant schools; they also note that these children feel less lonely. Children in migrant schools often felt segregated and did not have any interaction with local urban children. Interestingly their study even shows that there is little difference in learning outcome or loneliness between urban native children and migrant children who attend public schools. This has an important consequence on the education of migrant children.

The issue of the local context is primordial to reflect on social justice, marginalization and belonging in the Chinese context. As such not all migrant students share the same educational experiences. In their 2015 article Liu, Holmes and Albright examine Chinese urban school teachers' perceptions of educational inclusion of migrant students in both public and migrant schools. Although the previous paper reported better results and well-being of migrant children in general public schools, Liu et al. show that teachers in public schools were more accepting of inclusive classroom settings including both migrant and urban children. The teachers in the migrant schools believed that such settings can be problematic for migrant children since they tend to underperform and have behavioural issues. The authors draw the conclusion that teachers at migrant schools might be less ambitious towards educational inclusion of migrant students. The fact that these teachers are often under-qualified might play a role in their perception and lack of ambitious for the children. 
Let us finish with Chinese teacher education and how potentially migrant children, social justice and marginalization are taken into account. Like Finland, Chinese teacher education is multiform, and is provided by many different kinds of institutions. To our knowledge, the case of migrant children is hardly ever discussed in Chinese teacher education - although student teachers might volunteer in migrant schools to help them. The issue of social justice is also hardly taught in teacher education as such, and that seems to be reflected in the ways teachers reflect on their job. Wong (2014) shows, for instance, how little engagement with the issue is to be noted in teachers' individual publications or research activities, which serve as schoolbased professional development in China. She writes: "To promote a research atmosphere in schools, local education departments and educational research institutes from the state and universities are responsible for discussing and determining research topics for some selected schools to conduct. Such research collaboration is usually expert-led. Teachers, however, are also able to conduct small-scale school-based research, either at the individual or subject level, based on their interests and students' needs" (Wong, ibid.: 79). These practices have been common since the late 1980s and are used for teachers' annual appraisals and can lead to teacher promotion. In her analysis of teachers' publications, she found that none had engaged with critical reflection on social justice and equality/equity. She argues that this relates to the lack of discussions of these issues, and of the wider social context, in initial teacher education. In a similar vein, Wang and Gao (2013) show that social justice and equity were rarely discussed in the 2007 Free Teacher Education (FTE) program. The program, which was set up by the Chinese government, aimed at "attract(ing) outstanding students into the teaching profession and to channel quality teachers into schools located in underdeveloped rural areas" (Wang \& Guo, ibid.: 68). In return, a strong economic incentive is provided to the students. In interviews with some of the student teachers, the scholars have identified that they have a sense of superiority and moral ambivalence towards to objectives of the programme. The lack of 
engagement with discussions of social injustice and inequality during the training programme might have led the students to such attitudes.

\section{Conclusions}

In this article the concept of social justice in education, and more specifically in relation to marginalization and belonging, was deconstructed and problematised. We have demonstrated that this 'popular' concept is multifaceted and always ideologically marked - and thus impossible to generalise. We have also explained how the dominance of Americano-centric discourses on social justice in education can have a negative influence on the way we discuss social justice in other contexts. We thus feel that there is a need to include ideas, beyond 'Westernization', concerning these issues. At the end of the article the reader will have seen many different definitions and aspects of social justice in education. Again, we agree with Hackman (2006) that social justice needs to be problematized within a given (macro- and micro-) context, and with specific individuals. We do not believe that an effective approach to social justice is to give it a static definition, 'generalised' for every context of education. This might help us to avoid imposing certain ideologies onto others, to judge the other with our own criteria and/or to give the impression that one context is better than another. This might also avoid 'selling', as is the case of Finland through its current education export policy, illusionary solutions to be applied universally - but solutions which are based on 'white lies' and acontextualised anecdotes (See Schatz, 2016). We reiterate: every single context faces issues of social injustice, nolens volens.

We do believe that there is a point in comparing how social justice is understood and 'done' in various contexts (intra- and/or interculturally), starting from a clean plate and people's own perceptions. Comparing here means looking into both similarities and differences (Li \& 
Dervin, 2017). The case of China and Finland is interesting in this sense, especially in relation to migrant children. One might think that Finland is much more advanced than China for the issues under review. On the one hand, if one looks at different indicators and rankings Finland is readier than China. On the other hand, we need to explore the realities of what is happening in the classroom. How do teachers deal with examples of social injustice and marginalization? Are they able to identify them? How does a school create a sense of belonging? What do all these words mean in these different contexts? Could different contexts learn with each other about social justice - rather than from each other, or from one of them?

In order to do so there is a need for studies that show how social injustice can be turned concretely into justice in different contexts. About the two countries from this article, a lot has been published on the problems faced by children, their parents or schools but not enough about concrete actions that could make a difference. For Finland, we have found a large number of studies involving action research from the fields of intercultural and multicultural education. Yet, there is a need for more critical studies on how to make the 'intercultural' and 'multicultural' less essentialising, less culturalist (e.g. Layne, 2016; Alemanji, 2016). Very few such studies were identified about China. A couple of studies examining the positive impact of ICT to help rural and migrant students to narrow the gap with urban students (e.g. Bai et al., 2016) have been published. We believe for example that teacher education is key to developing strategies to deal with social injustice in education. It is thus important to design courses that train future teachers to reflect critically about cases of injustice in their classrooms and beyond, and to help them reflect on their role in dealing with them.

Finally, as we were writing this article, we were often puzzled by the discourses of some decision-makers, practitioners and even researchers about social justice in education. They appeared to be either empty or so polysemic that they made no sense. We thus encourage all 
(novice and confirmed) scholars, practitioners and decision-makers to (re-)negotiate the meanings of the concept of social justice in specific contexts and with specific individuals. This is important as social justice is about real people. And the only way we can help them or empower them to help themselves is by making it meaningful and understandable between us. Social justice might be a "feel-good phrase" to be recited as a mantra (Bialystok, 2014), yet, we should 'heal' it from its woes to make it work.

\section{References}

Abdallah-Pretceille, M. (1999). L'éducation interculturelle [Intercultural Education] (Paris: QSJ).

Alemanji, A. A. (2016). Is There Such a Thing...? A Study of Antiracism Education in Finland (Helsinki: University of Helsinki Press).

All-China Women's Federation Report (2013, May 11) Research Report on Rural Migrant Children and Left-Behind Children, China Education Daily.

Bai, Y., Mo, D., Zhang, L., Boswell, M., and Rozelle, S. (2016). "The Impact of Integrating ICT with Teaching: Evidence from a Randomized Controlled Trial in Rural Schools in China." Computers and Education 96: 1-14.

Batur, S. (2014). “Center and Periphery.” In: Teo, T. (Ed.). Encyclopedia of Critical Psychology. (New York: Springer), 212-215. 
Bell, L. A. (1997). “Theoretical Foundations for Social Justice Education.” In: Adams, M., Bell, L. A., and Griffin, P. (Eds.). Teaching for Diversity and Social Justice: A Sourcebook. (New York: Routledge), 3-15.

Bernelius, V. (2013). Eriytyvät kaupunkikoulut: Helsingin peruskoulujen oppilaspohjan erot, perheiden kouluvalinnat ja oppimistuloksiin liittyvät aluevaikutukset osana kaupungin eriytymiskehitystä [Segregation of Urban Schools: Differentiation of Pupil Population, Family Choice of Schools and Regional Effects on Learning as Part of Urban Segregation] (Helsinki: City of Helsinki Urban Facts).

Bialystok, L. (2014). "Politics Without "Brainwashing": A Philosophical Defence of Social Justice Education." Curriculum Inquiry 44(3): 413-440.

Bogoth, I. (2013). "Educational Theory: The Specific Case of Social Justice as an Educational Leadership Construct.” In: Bogotch, I., and Shields, C. M. (Eds.). International Handbook of Educational Leadership and Social (In)Justice. (New York: Springer), 51-65.

Brunila, K., and Kallioniemi, A. (2017). "Equality Work in Teacher Education in Finland." Policy Futures in Education. (online first).

Cambridge Dictionary. dictionary.cambridge.org

Cheng, A. (2008). Can China Think? (Paris: Publications du Collège de France).

Dervin, F. (2016). Interculturality in Education (Basingstoke: Palgrave). 
Dervin, F., and Hahl, K. (2015). "Developing a Portfolio of Intercultural Competences in Teacher Education: The Case of a Finnish International Programme." Scandinavian Journal of Educational Research 59(1): 95-109.

Dervin, F., Paatela-Nieminen, M., Kuoppala, K., and Riitaoja, A.-L. (2012). "Multicultural Education in Finland - Renewed Intercultural Competences to the Rescue?" International Journal of Multicultural Education 14(3): 1-13.

Fraser, N. (1997). Justice Interruptus. Critical Reflections on the 'Postsocialist' Condition (London: Routledge).

Gay, G. (2010). Culturally Responsive Teaching (New York: Teachers College Press).

Gewirtz, S. (1998). "Conceptualizing Social Justice in Education: Mapping the Territory." Journal of Education Policy 13(4): 469-484.

Giroux, H. (2003). “When Hope is Subversive.” Tikkun 19(6): 38-39.

Goody, J. (2006). The Theft of History (Cambridge: Cambridge University Press).

Hackman, H. W. (2006). "Five Essential Components for Social Justice Education.” Equity and Excellence in Education 38(2): 103-109.

Han, J. (2004). "Survey Report on the State of Compulsory Education among Migrant Children in Beijing." Chinese Education and Society 37 (5): 29-55. 
Han, J. (2017). Post-lingual Chinese Language Learning (Basingstoke: Palgrave).

Harinen, P., and Halme, J. (2012). Hyvä, paha koulu: Kouluhyvinvointia hakemassa [Good, bad school: searching for school well-being]. (Helsinki: UNICEF Finland. Finnish Youth Research Network).

Harju-Luukkainen, H., Nissinen, K., Sulkunen, S., Suni, M. \& Vettenranta, J. (2014). Selvitys maahanmuuttajataustaisten nuorten osaamisesta ja siihen liittyvistä taustatekijöistä PISA 2012-tutkimuksessa. Report on Migrant Youth Participation and Characteristics in 2012 PISA Studies]. (Jyväskylä: Jyväskylän Yliopisto koulutuksen tutkimuslaitos).

Harper, S. M. (2011). "Counting the Costs of a Global Anglophonic Hegemony: Examining the Impact of U.S. Language Education Policy on Linguistic Minorities Worldwide.” Indiana Journal of Global Legal Studies 18(1): 515-538.

Hayek, F. (1976). The Mirage of Social Justice (Sydney: The Centre for Independent Studies).

Holliday, A. (2013). Intercultural Communication and Ideology (London: Sage).

Holmes, P., Fay, R., Andrews, J. and Attia, M. (2016). "How to Research Multilingually: Possibilities and Complexities." In: Zhu, H. (Ed.) Research Methods in Intercultural Communication: A Practical Guide (New York: Wiley Blackwell), 88-102. 
Jokikokko, K. (2010). Teachers' Intercultural Learning and Competence (Oulu: Universitatis Ouluensis).

Kalalahti, M., and Varjo, J. (2012). "Tasa-arvo ja oikeudenmukaisuus perusopetukseen sijoittumisessa ja valikoitumisessa" [Equality and Justice in Admission and Selection to Basic Education]. Kasvatus \& Aika 6(1): 39-55.

Kilpi-Jakonen, E. (2011). “Continuation to Upper Secondary Education in Finland: Children of Immigrants and the Majority Compared”. Acta Sociologica 54(1): 77-106.

Kilpi-Jakonen, E. (2012). "Does Finnish educational equality extend to children of immigrants? Examining national origin, gender and the relative importance of parental resources." Nordic Journal of Migration Research 2(2): 167-181.

Kuukka, K., and Metsämuuronen, J. (2016). Perusopetuksen päättövaiheen suomi toisena kielenä (S2) -oppimäärän oppimistulosten arviointi 2015 [Finnish as a Second Language Syllabus Learning Outcomes in the 9th Grade of Basic Education in 2015]. Publications 13:2016. (Helsinki: The Finnish Education Evaluation Centre (FINEEC)).

Kuusisto, E., Kuusisto, A., Rissanen, I., Holm, K., and Tirri, K. (2016). “Finnish teachers' and students' intercultural sensitivity." Journal of Religious Education 63(2-3): 65-77.

Layne, H. (2016). “Contact Zones” in (Finnish) Teacher Education (Helsinki: Helsinki University Press). 
Layne, H., and Dervin, F. (2016). "Problematizing Finland's Pursuit of Intercultural (Kindergarten) Teacher Education.” Multicultural Education Review 8(2): 118-134.

Li, Y. \& Dervin, F. (2017). “Comparing and Contrasting How Social Justice is 'Done' in Education? Critical Reflections on China and Finland." Education and Society.

Linnansaari-Rajalin, T., Kivimäki, M., Ervasti, J., Pentti, J., Vahtera, J., \& Virtanen, M. (2015). “School Neighbourhood Socio-economic Status and Teachers' Work Commitment in Finland: Longitudinal Survey with Register Linkage." Teachers and Teaching: Theory and Practice, 21(2): 131-149.

Liu, T., Holmes, K. and Albright, J. (2015). “Urban Teachers' Perceptions of Inclusion of Migrant Children in the Chinese Educational Institution: A Comparative Study.” International Journal of Inclusive Education 19(9):1-15.

Lu, Y., and Zhou, H. (2012). "Academic Achievement and Loneliness of Migrant Children in China: School Segregation and Segmented Assimilation." Comparative Education Review 57(1): 85-116.

Luo, Y., Zhong, J. X., and Tsang, W. K. (2015) “进城务工人员随迁子女教育公平问题的分 配正义与关系正义之考察” [“An Empirical Analysis of Educational Equity among the Rural Migrant Children: Distributive and Relational Justice”]. 北京大学教育评论 [Peking University Education Review] 13(2): 146-167. 
McArthur, J. (2010). Achieving social justice within and through higher education: the challenge for critical pedagogy. Teaching in Higher Education 16(5), 493-504.

Menter, I. (2016). “Introduction.” In: Beauchamp, G., Clarke, L., Hulme, M., Kennedy, A. et al. (Eds.). Teacher Education in Times of Change (Bristol: Policy Press), 3-17.

Nieto, S. (2000). "Placing equity front and center: some thoughts on transforming teacher education for a new century." Journal of Teacher Education 51(3): 180-187.

Novak, M. (2000). “Defining social justice.” First Things 108: 11-13.

OECD (2015). PISA 2015 Results (Volume I). Excellence and Equity in Education (Paris: OECD Publishing).

Rawls, J. (1971). A Theory of Justice (Oxford, UK: Clarendon Press).

Riitaoja, A.-L. (2013). Toiseuksien rakentuminen koulussa. Tutkimus opetussuunnitelmista ja kahden helsinkiläisen koulun arjesta. [Construction of Otherness in Schools]. (Helsinki: Helsinki University Press).

Rikowski, G. (2000). "Education and Social Justice within the Social Universe of Capital." Paper presented at the BERA day seminar on "Approaching Social Justice in Education: Theoretical Frameworks for Practical Purposes", Faculty of Education, Nottingham Trent $\begin{array}{lllll}\text { University, } & \text { 10th } & \text { April, } & \text { 2000. } & \text { Retrieved }\end{array}$ http://www.leeds.ac.uk/educol/documents/00001618.htm 
Rizvi, F. (1998). “Some Thoughts on Contemporary Theories of Social Justice.” In: Atweh, B., Kemmis, S., and Weeks, P. (Eds.). Action Research in Practice: Partnerships for Social Rodriguez Medina, L. (2014). Centers and Peripheries in Knowledge Production (New York: Routledge).

Rosmini, A. (2007). The Constitution Under Social Justice (Lanham, MD: Lexington Books).

Rudolph, J., and Szonyi, M. (Eds.) (2018). The China Questions: Critical Insights into a Rising Power. (Boston: Harvard University Press).

Saari, M. (2011). "Promoting gender equality without a gender perspective: Problem representations of equal pay in Finland." Gender Work and Organisation 20(1), 36-55.

Sahlberg, P. (2015). Finnish Lessons. What can the World Learn from Educational Change in Finland? (New York, NY: Teachers College Press, Columbia University).

Schatz, M. (2016). Education as Finland's Hottest Export? A Multi-Faceted Case Study on Finnish National Education Export Policies (Helsinki: Unigrafia).

Sen, A. (2002). The Idea of Justice. (Boston: Harvard University Press).

Seppäinen, P., Kalalahti, M., Rinne, R. and Simola, H. (Eds.) (2015). Lohkoutuva peruskoulu: Perheiden kouluvalinnat, yhteiskuntaluokat ja koulutuspolitiikka [Segmenting Comprehensive 
School-Parental School Choice, Social Classes, and Education Policies] (Jyväskylä: Finnish Institute for Educational Research).

Shriberg, D., Song, S. Y., Miranda, A. H. and Radliff, K. (Eds.) (2013). School Psychology and Social Justice. Conceptual Foundations and Tools for Practice. (London: Routledge).

Singh, M. (2011). "Learning from China to Internationalise Australian Research Education: Pedagogies of Intellectual Equality and 'Optimal Ignorance' of ERA Journal Rankings." Innovations in Education and Teaching International 48(4): 355-365.

Sleeter, C. E. (2015, February). "Deepening Social Justice Teaching.” Journal of Language and Literacy Education. [Online]. Retrieved from http://jolle.coe.uga.edu/

Suni, M., and Latomaa, S. (2012). "Dealing with the Growing Linguistic Diversity in Schools: The Finnish Example.” In: J. Blommaert, S. Leppänen, P. Pahta, and T. Räisänen (Eds.). Dangerous Multilingualism: Northern Perspectives to Order, Purity and Normality (Basingstoke: Palgrave Macmillan), 67-95.

Tirri, T. (2014). "The last 40 years in Finnish teacher education.” Journal of Education for Teaching 40(5): 600-609.

Troyna, B., and Vincent, C. (1995). The discourses of Social Justice. Discourse: Studies in the Cultural Politics of Education 16: 149-166. 
Voipio-Huovinen, S., and Martin, M. (2012). "Problematic Plurilingualism - Teachers' Views.” In: Blommaert, J., Leppänen, S., Pahta, P. \& Räisänen, T. (Eds.). Dangerous Multilingualism: Northern Perspectives to Order, Purity and Normality (Basingstoke: Palgrave Macmillan), 96-118.

Wang, D. (2013). The Demoralization of Teachers: Crisis in a Rural School in China (Lanham, MD: Lexington Books).

Wang, D. \& Gao, M. (2013). "Educational equality or social mobility: The value conflict between preservice teachers and the Free Teacher Education Program in China." Teaching and Teacher Education 32: 66-74.

Wang, L., and Holland, T. (2012). "In Search of Educational Equity for the Migrant Children of Shanghai." Comparative Education 47(4): 471-487.

Wong, D. F. K., Li, C. Y., and Song, H. X. (2007). "Rural Migrant Workers in Urban China: Living a Marginalised Life." International Journal of Social Welfare 16: 32-40.

Wong, J. L. Y. (2014). "How Does Writing for Publication Help Professional Development of Teachers? A Case Study in China.” Journal of Education for Teaching 40(1): 78-93.

Xue, E and Liu A. (2017). 习近平教育思想: 中国教育改革的旗帜与方向. 中国教育学刊 5:

9-16 [Xi Jinping's Educational Thoughts: The Banner and Direction of China's Educational Reform. Journal of The Chinese Society of Education 5: 9-16]. 
Yang, D. (2016). 杨东平谈中国教育三大问题 (China faces three challenges in its education system). Retrieved from https://mt.sohu.com/20160623/n455957715.shtml

Yates, L., and MacLeod, J. (2000). "Social Justice and the Middle." Australian Education Researcher 27(3): 59-78.

Young, I. M. (1990). Justice and the Politics of Difference (Princeton, NJ: Princeton University Press).

Zhang, D. and Luo, Y. (2016). "Social Exclusion and the Hidden Curriculum: The Schooling Experiences of Chinese Rural Migrant Children in an Urban Public School.” British Journal of Educational Studies 64(2): 215-234.

Zhao, Y. (2014). Who's Afraid of the Big Bad Dragon?: Why China Has the Best (and Worst) Education System in the World (Hoboken, N.J.: Wiley, Jossey-Bass). 